\title{
Legal Enforcement by the Police against Child of Criminal Doer of a Traffic Accident Who Caused Death (Case Study in Traffic Accident of Police Traffic Unit of Cirebon City Police Juridiction)
}

\begin{abstract}
Anton Susanto $^{1}$, Ira Alia Maerani ${ }^{2}$ and Maryanto ${ }^{3}$
Abstract. The problems of this study were 1) the process of resolving the crime of traffic accident committed by a child which causing death in Jurisdiction Police Cirebon, 2) the difference between the completion of the crime of traffic accident by a child which causing death by perpetrators of adults in Police Cirebon City? 3) consideration of the law by the police in the Cirebon City Police enforcement of laws against the crime of traffic accident causing death committed by a child.

The method used is research that combines Juridical and Empirical. The source of research data derived from primary data and secondary data obtained by collecting documents and interviewing criminal cases with informants.

Based on research findings conducted by researchers regarding law enforcement in case of a traffic accident causing death committed by minors resolved with the criminal justice process method to process outside the criminal justice and restorative justice approach that is Diversion. Based on Act No. 11 of 2012 on the Criminal Justice System Child involvement of multiple stakeholders in the settlement became a mandatory provision. Constraints law enforcement officials in the execution of diversion itself is the factor of legal, officials law enforcement factors, community factors and factors of facilities and infrastructure.

Keywords: Law Enforcement; Police; Accident; Traffic; Child.
\end{abstract}

\section{Introduction}

Article 1 Paragraph (3) of the Constitution of the Republic of Indonesia 1945 (hereinafter referred to as the Constitution NRI 1945) confirmed that the Republic of Indonesia is based on the state law (rechtstaat). ${ }^{4}$ In Indonesia in order to enforce the state law as idealized, efforts need to be done so that people know the ins and outs of the law. Indeed, in these days in an effort to guarantee the maintenance of national stability steady to support the implementation of the development, the government has made various efforts, but in reality they only are the actions of community members who disrupt security and public order, either directly or indirectly, that will affect the pattern Their life.

There are some new developments that have not been accommodated by the traffic regulations. For example, a variety of alarms that should have been more. Although some rules have been accommodated through the Regional Regulation (Perda). Many provisions that have been left behind by the development of society, in addition to many legal provisions of habit, become unenforceable. For example, the necessity to put up with lighting at night against engined vehicles or motorized, hardly applies to goods and bicycle rickshaws. Repression against them almost never done, or if you do cause a reaction that is

\footnotetext{
${ }^{1}$ Student of Master of Law, Universitas Islam Sultan Agung Semarang and Police member, email: antonsusanto.me@gmail.com

${ }^{2}$ Lecturer of Faculty of Law, Sultan Agung Islamic University (UNISSULA), Semarang

${ }^{3}$ Lecturer of Faculty of Law, Sultan Agung Islamic University (UNISSULA), Semarang

${ }^{4}$ Bambang Waluyo 2004, Pidana Dan Pemidanaan, Sinar Grafika, Jakarta, p. 33.
} 
less comfortable for the officers themselves. Such reactions do not arise only from the perpetrator, but also of the citizens. ${ }^{5}$

With regard to reaching the goal of criminal justice, each officer of the law (police, prosecutor, judge) even though their duties vary but they must work in an integrated system, which means that each officer working of the law should be functionally related. In this case, the criminal justice viewed as a system, as in the criminal justice there are several agencies that each have the authority and duties in accordance with their field and regulations. Although in criminal justice there are various components, but the goal of all these institutions are tackling crime (Over coming of crime) and crime prevention (Prevention of crime). Therefore, the criminal justice system must be built on social processes in the society. ${ }^{6}$

In addition, minors are not allowed to drive a motor vehicle so as not to endanger other motorists on the road according to the rules set out in Article 311 of Act No. 22 Of 2009 regarding Traffic and Road Transportation. The fact there is a traffic violation is a traffic accident that occurred in the jurisdiction of Police Cirebon according to the police report No. 362 / IX / 2016 / So what happened on Sunday September 182016 Wahidin Village Sukapura District of attorney Cirebon, between minibus Innova with No. Pol: E-1531-KU driven by Muhamad Ramdan Mardani Bin Eman Permana with Motorcycles Honda Scoopy No. Pol: E-5333-LY piloted by Desija Binti Sani with Carila Binti Sukirna and collide again with a public transportation vehicle No. Pol: E-1912-A, driven by Dadang Kusdinar Bin Kusmara. Where accidents that resulted in the victim Desija Binti Sani died and Carila Binti Sukirna injuries and suffered material losses. This accident is settled amicably by both parties. Appropriate legislation required police to use settlement diversion in case of criminal offenses by children because the perpetrator by a child as stipulated in Article 7 paragraph b of Act No. 11 Of 2012 on Child Criminal Justice System. Carila Binti Sukirna injuries and suffered material losses. This accident is settled amicably by both parties. Appropriate legislation required police to use settlement diversion in case of criminal offenses by children because the perpetrator by a child as stipulated in Article 7 paragraph b of Act No. 11 Of 2012 on Child Criminal Justice System. Carila Binti Sukirna injuries and suffered material losses. This accident is settled amicably by both parties. Appropriate legislation required police to use settlement diversion in case of criminal offenses by children because the perpetrator by a child as stipulated in Article 7 paragraph b of Act No. 11 Of 2012 on Child Criminal Justice System.

Based on the background of the problems that have been described, it can be used to discuss a problem as follows: How the process of resolving the crime of traffic accident committed by a child which causing death in Cirebon City Police Jurisdiction?; What is the difference between the completion of the crime of traffic accident by a child which causing death by perpetrators of adults in Cirebon Police Juridiction?; What are the legal considerations by the Police of the Cirebon City Police in law enforcement against criminal acts of a traffic accident causing death committed by a child?

\section{Research methods}

\footnotetext{
${ }^{5}$ Subanindyo Hadiliwuh, Undang-undang Lalu Lintas Sebagai Regulasi tertib Lantas Kota Medan, Jurnal Equality, Universitas Sumatera Utara, Vol. 11 No. August $2^{\text {nd }}, 2006, p .135$.

${ }^{6}$ Yesmil Anwar and Adang, 2009, Sistem Peradilan Pidana Konsep Komponen Dan Pelaksanaannya Dalam Penegakan Hukum Di Indonesia, Widya Padjadjaran, Bandung, p. 28.
} 
The method used is research that combines Juridical and Empirical. The source of research data derived from primary data and secondary data obtained by collecting documents and interviewing criminal cases with informants.

\section{Results and Discussion}

\subsection{The Process Of Settlement Of The Crime Of Traffic Accident Committed By Child Which Causing Death In Cirebon City Police Jurisdiction}

Law Enforcement in Indonesian known some terms outside of law enforcement, such as the application of the law. But it seems that law enforcement term is most often used and thus in the future will be increasingly well-established term or a term that is used. The law must be enforced and implemented, everyone expects to enactment of the law in the event of events. That's how the law should apply basically should not deviate even though the world is crumbling law must be upheld. ${ }^{7}$

Efforts settlement process as a diversion on criminal cases of traffic accidents that cause death in Unit of traffic accident Unit Cirebon Police Juridiction, as required for the completion of the criminal assault of children are set out in Article 7 (1) of Act No.11 Of 2012 on the Criminal Justice System Child. In this process the researchers put the theory of law enforcement / legal certainty, since the regulation itself SPPA Act obliges the process was started. The way out is taken by police investigators to solve criminal cases of traffic accidents, especially with a child offender is Diversion in this case as part of efforts for resolving cases of traffic accidents criminal offenses by police in Cirebon Police Traffic Unit of the City.

Diversion provisions specifically set out in Article 6 to Article 16 of Act No. 11 of 2012, but its implementation rules will be set out in government regulations. Form of implementation of diversion set out in this provision is done through discussions that involve Child and parent / guardian, victim and / or parent / guardian, the supervising social, and professional social workers, and may also involve Labor Social and / or community.

The implementation process of diversion hold the principle of restorative justice with respect to: the interests of the victim; Children's welfare and responsibilities; avoidance of negative stigma; avoidance of retaliation; harmony of society and propriety, decency and public order. Investigators, prosecutors and judges when considering whether a diversion will be implemented or not, must pay attention to: the category of criminal offenses committed by children; age of children; the research community of BAPAS; losses incurred on the behavior of children; How can the level of attention and public opinion on the case; and the support of family and community environment.

Investigators put forward the arrest of humanitarian and consider whether certain age the child needs to be arrested or not, even the investigator / police must prioritize the best interests of the child into consideration treatment or not. The parties may make an arrest at the level of investigation is not the police, but there are special officers namely Child Placement Institutions While (LPAS), and if LPAS not yet exist, can be detained by the Institute of Social Welfare Implementation. ${ }^{8}$

\footnotetext{
${ }^{7}$ https://knowledgeisfreee.blogspot.com/2015/10/pengertian-penegakan-hukum-kedasaran.html, Downloaded dated December 31, 2019 12:33 hours GMT.

${ }^{8}$ Interview with Chief Unit Inspector Laka Rosidi, SH, on Monday, February 3, 2020 at 09.00 am.
} 
The process of settlement of diversion in criminal cases of traffic accidents that cause death in Traffic Accident Unit of Cirebon Police Juridiction, as required for the completion of the criminal assault of children are set out in Article 7 (1) of Act No.11 Of 2012 Child on the Criminal Justice System.

\subsection{The Difference Between The Completion Of The Crime Of Traffic Accident By Child Which Causing Death By Perpetrators Of Adults In Cirebon Police Juridiction}

The criminal act is distinguished by systematics of the Criminal Code, which is the second book that contains the felony and the third book that contains the crime of violation. Crime is an act which is based on the quality or nature of the act is reprehensible, regardless of the issue of whether there is a stipulation in the legislation as a criminal offense. Instead offense is the act that is seen as a despicable act as criminal acts solely as stipulated by legislation. ${ }^{9}$

Certainty / law enforcement must remain prioritized justice, as well as in the handling of criminal cases. But in this case the completion of criminal offenses seen differences of offenders or suspects their age difference. Here's the difference to the researcher criminal settlement between the perpetrator of children with adult offenders in the process include: The examination stage; Investigation process;Stage prosecution; Stage of the examination in court

The differences really stand out for examination in court for child and adult cases is for a child case hearing is otherwise closed to the public except for the reading of the verdict. Children in the process of the proceedings in the trial in the courtroom especially for children. then for the child waiting room waiting room is distinguished by an adult. Children in proceedings in court shall be accompanied by a parent / guardian, lawyer or other legal aid providers, social workers and counselors professional community. As for the case of adults process hearing is declared to the public, and are not required to be accompanied by parents or tutors of society, but it must be accompanied by the attorney / advocate. ${ }^{10}$

The difference between the completion of the crime of traffic accident by a child which causing death by perpetrators of adults in Cirebon Police Juridiction is there a difference regarding the completion of the crime of lacquer and then in the Traffic Accident Unit of Cirebon Police Juridiction, from the examination stage of investigation, prosecution and examination among the suspects adult court and cases involving suspects a child is very obvious difference, in terms of setting already clearly different. For handlers suspect cases of adults using the settings according to the provisions of Act No. 8 of 1981 on Criminal Proceedings. As for the case that suspects child is applicable principle lexspecialis derogat legi generalis using special arrangements juvenile justice system as well as the provisions of Act No. 11 Of 2012 on Child Criminal Justice System. In addition to handling cases related to children, in the handling of the completion of the crime is promoting the protection and best interests of children.

\subsection{Legal Consideration By The Cirebon City Police In Law Enforcement Against Criminal Acts Of A Traffic Accident Causing Death Committed By Children}

\footnotetext{
${ }^{9}$ Sudaryono and Natangsa Surbakti, 2005, Buku Pegangan kuliah Hukum Pidana, Faculty of Law, Universitas Muhammadiyah Surakarta, p. 131.

${ }^{10}$ Interview with Chief Unit Inspector Laka Rosidi, SH, on Monday, February 3, 2020 at 09.00 am.
} 
Accidents do not happen by chance, but there is. Therefore, there is cause, the accident must be analyzed and discovered, so that corrective action to cause it to do as well as the preventive measures more accidents can be prevented. Accidents are unplanned actions and uncontrolled, when the actions and reactions of objects, materials, or radiation causes injury or possible injury. ${ }^{11}$

To get justice before the law, the assistance should be done indiscriminately or status and other factors. According to Act No. 11 of 2012 on the Criminal Justice System Child, the police as law enforcement agencies and the justice of the first handle this case in particular for handling the case of traffic accidents that cause death by child actors. So that the police shall explore, and understand the legal values that live in the community, hence the role and position of the child is very exclusive and guaranteed by law. Appropriate consideration can provide the fairest decision on criminal acts that are legally and is also the most important things that will have a big impact on the child. Therefore,

Police Cirebon especially Unit Laka Cirebon City Police of promoting justice Restorative with completion of criminal case involving offenders, victims, families perpetrator / victim, and other relevant parties to work together to find a fair settlement with the emphasis on restoring back to the original condition , and not retaliation. ${ }^{12}$

Legal considerations by the Police Cirebon Police Juridiction in the enforcement of the law against the crime of traffic accident causing death committed by a child is enforcement by the police against the crime of traffic accidents conducted by the Children's Traffic Accident Unit of Cirebon Police Juridiction, especially in the case number: 362 / IX / 2016 / Then, on September 18, 2016, law enforcement is using settlement Diversion with the many efforts made by some people to be taken into consideration, such as the child is aged 16 years and 10 months, during school-behaved, amicably agreed to deliberation between the suspects, victims and witnesses, $\mathrm{ABH}$ agreed for the implementation of diversion and got a versioned determination of the court.

\section{Closing}

\subsection{Conclusion}

- The process of settlement of diversion in criminal cases of traffic accidents that cause death in Traffic Accident Unit of Cirebon Police Juridiction, as required for the completion of the criminal assault of children are set out in Article 7 (1) of Act No.11 Of 2012 Child on the Criminal Justice System

- There are differences regarding the completion of the crime of lacquer and then in the Traffic Accident Unit of Cirebon Police Juridiction, from the examination stage of investigation, prosecution and trial of suspects adults and cases involving suspects a child is very obvious difference, in terms of Setting already clearly different, For handlers suspect cases of adults using the settings according to the provisions of Act No. 8 of 1981 on Criminal Proceedings. As for the case that suspects child is applicable principle lexspecialis derogat legi generalis using special arrangements juvenile justice system as well as the provisions of Act No. 11 Of 2012 on Child Criminal Justice System. In addition

11 http://arfandisade-as.blogspot.com/2012/08/kecelakaan-lalu-lintas.html, Accessed on January 10, 2020 $16: 30 \mathrm{pm}$.

${ }^{12}$ Interview with Chief Unit Inspector Laka Rosidi, SH, on Monday, February 3, 2020 at 09.00 am. 
to handling cases related to the child,

- Enforcement by the police against the crime of traffic accidents conducted by the Children's Traffic Accident Unit of Cirebon Police Juridiction, especially in the case number: 362 / IX / 2016 / Then, on September 18, 2016, law enforcement is using settlement Diversion with the many efforts made by some people to be taken into consideration, such as the child is aged 16 years and 10 months, during school-behaved, agreed to deliberation amicably between the parties suspects, victims and witnesses, agreed the implementation of diversion for $\mathrm{ABH}$ it and got a versioned determination of the court

\subsection{Suggestion}

- For law enforcement officials, especially the police as protectors and servants of the people the frontline between the law enforcement community should be obliged to seek the settlement of children with diversion efforts, though eventually the child offender and the victim later opt for the other settlement efforts;

- To the parents of children as offenders, and community institutions such as BAPAS, community leaders and other important role in assisting children as perpetrators of a crime, should they consider the interests of the rights of child. Children as the offender shall be assisted, so that they receive direction and guidance, so that their future for the better. With the implementation of the Diversion should be able to minimize the number of crimes committed by minors;

- To the local government, should put forward a concern for the children either in school or as perpetrators, although children as perpetrators of crimes are entitled to legal protection from the government, because children are the future generation. If the rights of juvenile offenders can be protected and cared for so that their future can change the future for the better. All actions taken by the government against juvenile offenders continue to refer to the rules applicable, if the case of children are able to be resolved by discussion or consensus, then advisable diversion can be accomplished, so that the government's goal of protecting the rights of children as perpetrators of violence can be protected.

\section{References}

[1] Bambang Waluyo 2004, Pidana Dan Pemidanaan, Sinar Grafika, Jakarta

[2] Subanindyo Hadiliwuh, Undang-undang Lalu Lintas Sebagai Regulasi tertib Lantas City of Medan, Jurnal Equality, Universitas Sumatera Utara, Vol. 11 No. August 2nd, 2006

[3] Sudaryono and Natangsa Surbakti, 2005, Buku Pegangan kuliah Hukum Pidana, Faculty of Law, Universitas Muhammadiyah Surakarta

[4] Yesmil Anwar and Adang, 2009, Sistem Peradilan Pidana Konsep Komponen Dan Pelaksanaannya Dalam Penegakan Hukum Di Indonesia, Widya Padjadjaran, Bandung

[5] https://knowledgeisfreee.blogspot.com/2015/10/pengertian-penegakan-hukumkedasaran.html, Downloaded clock dated December 31, 2019 12:33 pm

[6] http://arfandisade-as.blogspot.com/2012/08/kecelakaan-lalu-lintas.html, Accessed on January 10, 2020 16:30 pm. 